\title{
Essay on the Geography of Plants
}

Alexander von Humboldt and Aimé Bonpland. Edited and with an Introduction by Stephen T. Jackson. Translated by Sylvie Romanowski. 2009. University of Chicago Press, Chicago. Pp. 296, 1 color plate, 9 halftones, 7 tables, 1 poster. \$45.00 (cloth). ISBN 9780226360669.

Reviewed by lan C. Smith

Reviewer address: Department of Anthropology, University of Arkansas, Fayetteville, AR 72701. icsmith34@gmail.com

Received: November 1, 2011

Volume: 4:28-29

Published: February 14, 2013

(C) 2013 Society of Ethnobiology

Alexander von Humboldt established himself as one of the fathers of modern day biogeography when he wrote his Essai sur la Géographie des Plantes and accompanying Tableau Physique des Andes et Pays Voisins. This essay, based on scientific observations collected from a five year scientific expedition and journey from 1799-1804 through the Americas with Aimé Bonpland, was first presented in 1807. In Cosmos and other writings, Humboldt provided many intellectual insights to our modern understanding of the world including the similarity of plants growing at higher altitudes to those growing at lower and higher latitudes and the historical positions of the continents. A highly distinguished scientist in his own time and a contemporary of Charles Darwin, Alfred Russell Wallace, and a multitude of influential scientific minds, Humboldt has faded from today's public consciousness. This may not be the case for long.

Stephen T. Jackson, professor of botany and ecology at the University of Wyoming, and Dr. Sylvie Romanowski, associate professor of French literature at Northwestern University, have collaborated to produce a wonderful contribution to ethnobiology. A chance meeting while traveling led to the cooperation between the authors, an event resulting in a book that should prevent future frustration for readers while staying as close to the original 18th century writing as possible. Born from Dr. Jackson's frustration as an English speaker trying to understand botanical details from Humboldt's Essai and Tablean in the original French, this work grants the English reader of natural history and biogeography greater access to the ideas and writings of Alexander von Humboldt and Aimé Bonpland.
In their Essay on the Geography of Plants, the authors have succeeded in fluently presenting Humboldt's foundational ideas. Building from an English translation of Humboldt's Essai by Sylvie Romanowski, the authors provide context and detail, enabling them to paint a picture of how Humboldt, as a travelling botanist and polymath, has stimulated the science of historical ecology. The inclusion and analysis of Humboldt's Tableau by the authors reveals Humboldt's observation of the global pattern of plants and geography. A poster-sized color reproduction of Humboldt's Mt. Chimborazo tableau is a beautiful addition to the text. The contents of the book are arranged in a manner that guides the reader towards a deeper understanding of the central translated essay.

Following the preface, several notes to the reader, and acknowledgements, the reader is introduced to Humboldt and his work. Here Jackson eloquently expresses his respect for Humboldt and his contributions to science. This passage transitions nicely to a reading of the translation of Humboldt's essay and his Tableau Physique. A short chapter analyzing the science of the Tableau and a listing of the scientific names within the Tableau is provided next.

Humboldt and Bonpland did not have modern GIS technology, yet they used particular instruments such as the chronomoter to observe the spatial interrelationship of biotic and abiotic systems. Jackson addresses this topic with a short essay detailing why those instruments were hauled by the scientists and their crews over the mountains and rivers of the continent to explore their numerous hypotheses including those on longitude, latitude, and elevation (p. 221). The biographical sketches and bibliographical essay provide supplementary information for the reader looking for a comprehensive understanding of 
the leading scientific and political figures mentioned in the Essai and Tablean as well as how this work relates to additional books and essays on Humboldt. Jackson and Romanowski's level of footnoting remains measured throughout which adds valuable information without detracting from the reader's experience of the main text.

This book benefits from a thoughtful and wellorchestrated layout that introduces Alexander von Humboldt as the scientist, writer, and man that current and past ethnobiologists have benefitted from. As Jackson echoes Humboldt from his Essai, the purpose of his work is to appeal to botanists to "go beyond collecting, describing, and classifying plant specimens...to focus on the geography of plants" (p.18). A more holistic approach to botany was pioneered by Humboldt. This concept of the important role of ecological knowledge remains important today. Translated into English and bookended by a well written introduction and supplemental information on the life and times of Humboldt, it is quite possible that Essay on the Geography of Plants will cause you to develop the "Humboldt virus" (p. vii) shared by Jackson and Romanowski. 